\title{
Germination Characteristics of Two Varieties of Kochia Prostrata (L.) Schrad.
}

\author{
S.S. WALLER, C.M. BRITTON, D.K. SCHMIDT, J. STUBBENDIECK, AND F.A. SNEV A
}

\begin{abstract}
Kochia prostrata (L.) Schrad. (prostrate summer cypress) is a perennial, half-shrub native to the arid and semiarid regions of Russia, central Europe, and the eastern Mediterranean. It is drought resistant, salt tolerant, winterhardy forage which is desirable for big game browse. $K$. prostrata has potential for revegetating critical areas on western rangelands. Since limited research has been reported on germination characteristics, the effects of harvest date, seed drying procedures, length of storage, and storage temperature on germination were evaluated for $\boldsymbol{K}$. prostrata var. virescens and var. canescens. Seed was collected from nursery plots at the Squaw Butte Station, Burns, Ore., on 6 harvest dates (September 20 to November 9,1978 ). Seed was aid-dried or dried at $30^{\circ} \mathrm{C}$ for 24 hours and one seed lot was germinated immediately, while 3 seed lots were stored for 3 months at $-18,4$, or $21^{\circ} \mathrm{C}$ prior to germination trials. $K$. prostrata var. canescens consistently exhibited higher $(p<.05)$ germination percentages than var. virescens. The effect of harvest date was also significant $(p<.05)$ as both varieties exhibited higher average germination percentage at later harvest dates. Apparently, seeds of either variety did not fully mature until approximately October 20 during the 1978 growing season. Drying procedure affected germination only when seeds were stored for 3 months. Under these conditions air-dried seed had a higher $(p<.05)$ average germination than dried $(44.5$ and $38.3 \%$, respectively). Higher $(p<.05)$ germination occurred following 3 months of storage at $4^{\circ} \mathrm{C}$ for both varieties (69.4 and $37.9 \%$ for var. canescens and virescens, respectively). $K$. prostrata var. canescens collected on November 9,1978 , air-dried and stored for 3 months at $4^{\circ} \mathrm{C}$ had the highest germination (97\%).
\end{abstract}

Five species of Kochia are commonly found in the United States. Two are native, perennial half-shrubs: Kochia americana and $K$. californica, while 3 are annual, introduced forbs: $K$. alata, $K$. trychophylla and K. scoparia (Shetler and Skog 1978). Kochia is a member of the Chenopodiaceae or Goosefoot family which includes such desirable species of the western range as saltbush (Atriplex) and winterfat (Eurotia). The native, perennial species of Kochia are considered low producing but valuable forage species while others such as $K$. scoparia are well known high producers but considered a weed in cultivated land (Keller and Bleak 1974).

Several accessions of another species, $K$. prostrata (L.) Schrad. commonly called prostrate summer cypress were introduced into the United States in 1961 by the New Crops Resea rch Branch of the Agricultural Research Service (Keller and Bleak 1974). It is native to arid and semiarid regions of central Eurasia where it grows on alkaline, stony, and sandy steppes and plains. $K$. prostrata is a

\footnotetext{
Authors, at the time of the research, were associate professor, Agronomy Department, University of Nebraska-Lincoln; associate professor, Rangeland Resources Program, Oregon State University; graduate st udent; associate professor, Agronomy Department, University of Nebraska-Lincoln; range scientist, USDA, ARS, Squaw Butte Station. Britton is currently associate professor, Range and Wildlife Sciences Department, Texas Tech University, Lubbock.

This study includes cooperative investigations of the Nebraska Agricultural Experiment Station, Oregon State Agricultural Experiment Station and Science and Education Administration-AR, U.S. Department of Agriculture. Published as Paper Number 6564, Journal Series, Nebraska Agricultural Experiment Station.

Manuscript received July 29, 1981.
}

generally long-lived highly variable, woody based half-shrub. It ranges in height from less than 0.3 to $1 \mathrm{~m}$. Ascending branches are covered with short to long woolly hairs. Leaves are flat, linear to filiform and hairy (Shishkin 1936). It is a drought resistant and winterhardy. Consequently it is adapted to semidesert and mountainous zones within the USSR (Balyan 1972). Keller and Bleak (1974) reported that the species appeared to be well adapted to the climate and soils of the intermountain area of the western United States. Two accessions (PI314929 and PI358941) proved to be highly salt tolerant in a greenhouse study (Francois 1976). It was concluded that either accession should be well adapted for planting in the salt affected western rangelands of the United States (Francois 1976).

Shishkin (1936) considered prostrate summer cypress a valuable shrub for browse in the Asiatic region of the USSR where it has been used by sheep, goats, camels, and horses. McArthur et al. (1974) suggested that it would be a valuable multi-purpose shrub on neutral, saline, or alkaline soils in the intermountain region of the United States. Preliminary observations in Utah indicated that this species is sought out by mule deer (Blauer et al. 1976). It can provide important sources of protein and carotene without risks of livestock poisoning from excess tannin or oxalates (Davis 1979). Production and chemical content of $K$. prostrata indicated an excellent potential for forage production on western ranges (Britton and Sneva 1977). Blauer et al. (1976) considered that superior strains of $K$. prostrata for forage and cover could be obtained by breeding.

Prostrate summer cypress is highly polymorphic and consists of numerous geographical races and ecotypes (Shishkin 1936). Balyan (1972) reviewed the existing taxonomic classification of prostrate summer cypress and determined that there is no common opinion in this concern. Species, varieties, and ecotypes have all been classified under similar names by various authors. He recognized the "gray form" as a subspecies [Kochia prostrata (L.) Schrad. Subsp. grisea Prat.] with two varieties: var. villosocansa Bong et Mey. and var. canescens Mog. The "green form" was Kochia prostrata (L) Schrad. Subsp. virescens (Frenzl) Prat. However, the gray and green forms were later recognized as varieties, var. canescens (PI358941) and var. virescens (Pl314929), respectively by Britton and Sneva (1977).

Germination studies on $K$. prostrata have been restricted to material harvested in regions in which the plant is native. Under natural conditions of growing and cultivation, prostrate summer cypress only grows in the spring. Field-fresh seeds had a period of post-harvest dormancy of 4 to 5 months; however, 20 to $30 \%$ germinated on the first day (after harvest) under laboratory conditions (Balyan 1972). Seeds of the early ripening green variety completed post-harvest ripening at 4 to 4.5 months while the late ripening gray variety required 5 to 6 months(Balyan 1972). Germination of $63 \%$ in freshly harvested seeds was increased to $89 \%$ after storage for 3 months at room temperature and was decreased to 41 and 5\% after storage for 6 and 8 months, respectively (Demin et al. 1977). However the highest germination of a mountain ecotype was noted 5 to 6 months after harvest. Generally, seed viability 
diminished within 5 to 7 months under natural conditions (Balyan 1972).

A considerable part of the nutritive substance was lost if seeds stored for 5 months contained $14 \%$ or more moisture. Reducing the moisture content to $7 \%$ by drying prior to storage reduced this loss (Balyan 1972). The reduced moisture level extended viability of seeds 10 to 12 months.

The periods of seed ripening of the different subspecies and varieties are not equal (Balyan 1972). In the Issykkul basin of the USSR, the greenish variety ripens on September 20 to 30 while the gray on October 10 to 20 . The seeds ripen unevenly with those on the lower part of the raceme ripening first. This process can require 30 days (Balyan 1972).

This research was designed to complement current investigations by researchers at the Squaw Butte Experiment Station (Burns, Oregon) regarding the usefulness of $K$. prostrata as a rehabilitation species for western ranges. Two varieties, var. virescens (green) and var. canescens (gray) were used to evaluate date of harvest and post-harvest management for maximum seed germination.

\section{Materials and Methods}

Kochia prostrata var. canescens (gray) and $K$. prostrata var. virescens (green) were established in nurseries in 1970 at the Squaw Butte Experiment Station, Burns, Ore. The area (elevation $1360 \mathrm{~m}$ ) was a nonirrigated sandy loam site (Abruptic Xerollic). The annual precipitation is $29.7 \mathrm{~cm}$ and $30 \%$ of the total precipitation occurs during the growing season. Ten plants of each variety were randomly chosen for harvest on each of 6 dates beginning on September 20 and continuing at 10-day intervals until November 9 , 1978. The phenological stage was recorded for each harvest date to allow application of this data to subsequent years. One-half of the seed stems collected from each variety was dried at $30^{\circ} \mathrm{C}$ for 24 hours (dried) and the remainder was air-dried for 7 days.

Following harvesting and drying, plant material was forwarded to the University of Nebraska-Lincoln for further processing and germination trials. Stems were rubbed lightly to remove the seed and chaff. Partial separation of seed from chaffy material was accomplished using a South Dakota Blowerl. Seeds were separated and counted by hand into 100 seed groups by variety, harvest datc, and drying procedure. Moisture content of the seed was determined by drying at $72^{\circ} \mathrm{C}$ until a constant weight.

Seed transport and preparation following each harvest required approximately three weeks during which time seeds were kept at room temperature. Following this period of preparation one seed lot was placed in the germinator ( 3 weeks after harvest) and at the same time a 3-month storage period was begun for the remaining seed lots at temperatures of $-18,4$ or $21^{\circ} \mathrm{C}$. Each treatment was replicated 5 times, a replication consisted of 100 seeds on a double layer of moist filter paper in a petri dish. Thirty-day germination trials were conducted in a germinator programmed to alternate from $15^{\circ} \mathrm{C}$ for 16 hours (dark period) to $25^{\circ} \mathrm{C}$ for 8 hours (light period). Trials were checked daily for moisture and germinated seeds counted every 3 days. A seed was considered to have germinated when the radicle, hypocotyl, and 2 cotyledons were extended approximately $5 \mathrm{~mm}$ from the calyx.

To make comparisons of storage versus no storage, seed stored 3 months at $21^{\circ} \mathrm{C}$ was compared to seed germinated 3 weeks after harvest. The effect of variety, harvest date, and drying procedure were also evaluated in this comparison. The same seeds stored 3 months at $21^{\circ} \mathrm{C}$ were compared to those stored 3 months at $-18^{\circ} \mathrm{C}$ and $4^{\circ} \mathrm{C}$ to determine the effect of the 3-month storage temperature. Means were separated using Tukey's (honestly significant difference) HSD (Steel and Torrie 1960).

\section{Variety}

\section{Results and Discussion}

Percentage germination was significantly different $(p<.05)$ for

${ }^{1}$ Mention of product na mes in this pa per does not constitute a recommendation by the Nebraska Agricultural Experiment Station.

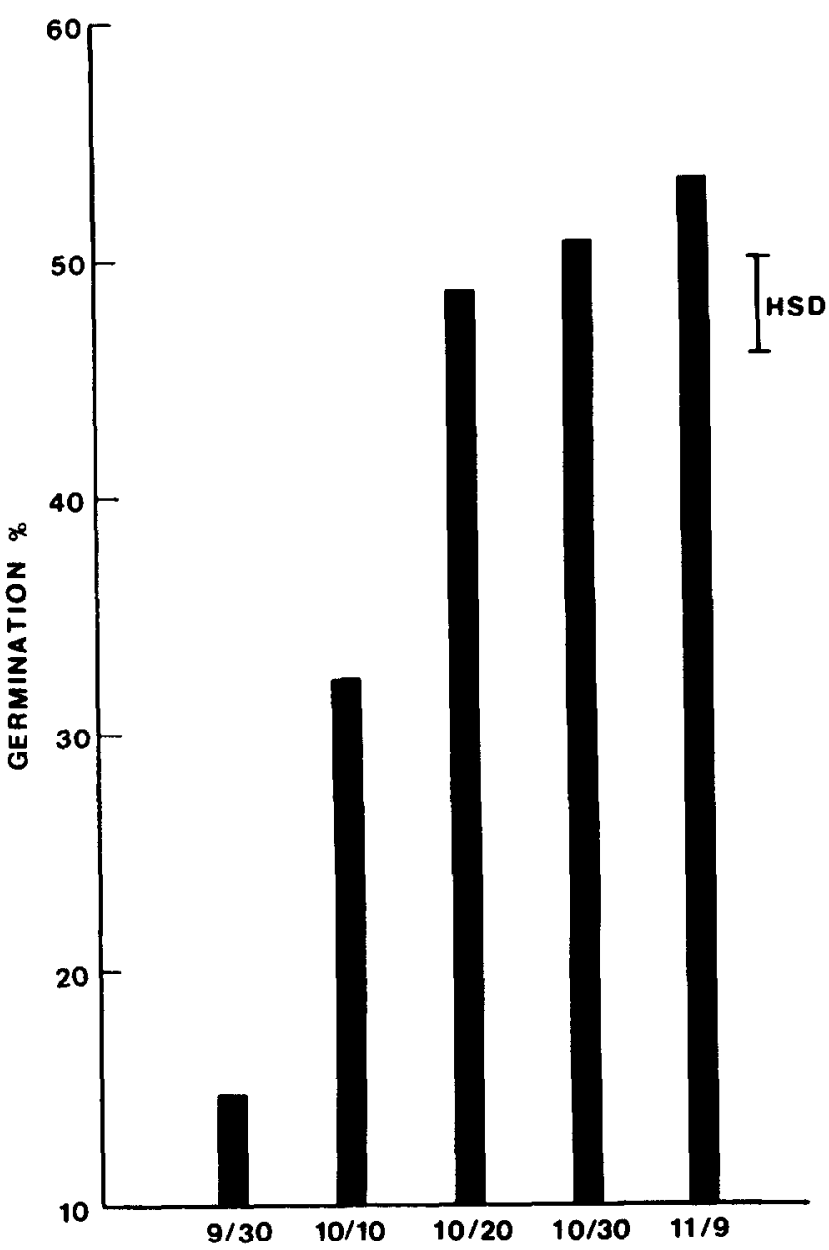

Fig. 1. The effect of harvest date averaged over variety, drying procedure, and storage on 30-day germination of Kochia prostrata. Values were calculated using a sample size of 40 . Tukey's honestly significant difference (HSD) was 4.03 .

the 2 varieties. Regardless of harvest dates, drying.procedure or storage, the gray variety exhibited higher germination percentages than the green (overall means of 50.9 and 29.2, respectively). The gray variety consistently germinated earlier in the 30 -day germination period.

\section{Harvest Date}

Harvest date also significantly $(p<.05)$ affected germination (Fig. 1). Seeds harvested on September 20 we re immature and data obtained were not used in the factorial design. Percentage germination averaged over variety, drying procedure and storage increased from approximately $14.8 \%$ for seeds harvested on September 30 to $53.7 \%$ for seeds harvested on the last date. However, germination percentage of seeds collected on October 20 was not significantly ( $>$.05) different than those collected on October 30 or November 9. Most ungerminated seeds in the trials were not considered mature because of unfilled endosperm until the October 20 harvest date. Evidently seed was maturing during the time interval of the first 3 harvest dates from September 20 to October 10, 1978. Apparently, the developmental stage for optimum germination could be judged in the field stage when the seeds could be easily hand stripped from the inflorescences. This stage was reached on October 20 for the green variety and October 30 for the gray variety.

The gray variety germinated better at each harvest date and significantly better than the green at all dates except October 20 (Fig. 2). Within both varieties germination significantly $(p<.05)$ increased with a delay in harvest except for the last 2 harvests. 


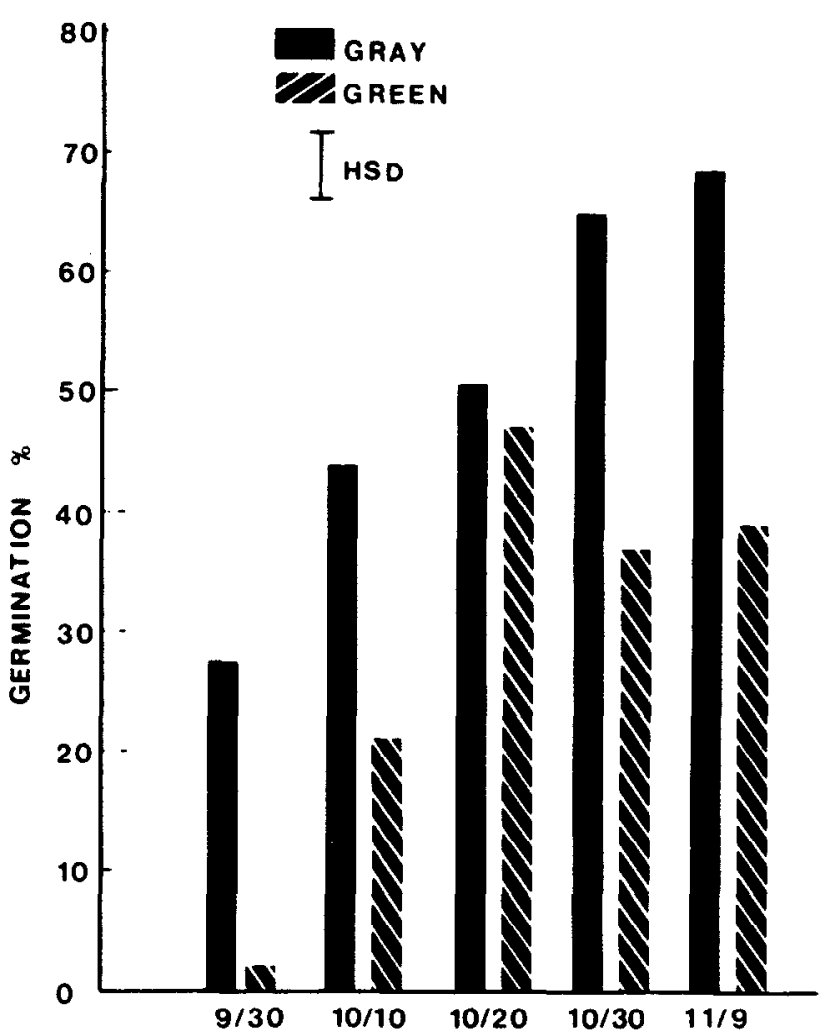

Fig. 2. The effect of harvest date on 30-day germination percentage for Kochia prostrata var. canescens (gray) and $\mathbf{K}$. prostrata var. virescens (green) averaged over drying method and storage. Values were calculated using a sample size of 20. Tukey's honestly significant difference (HSD) was 5.70 .

\section{Drying Method}

The drying method significantly affected $(p<.05)$ germination when averaged over variety, harvest date, and storage. Air-dried seeds averaged $42.0 \%$ germination while $38.2 \%$ of the dried seeds germinated. This was primarily because the air-dried seeds stored 3 months germinated much better $(44.5 \%)$ compared to seeds dried and then stored 3 months (38.3\%). However, the effect of drying method was not significant $(p>.26)$ when seeds were germinated without storage. Moisture content of air-dried and dried seeds prior to germination or storage was approximately the same within both varieties. Moisture content varied from approximately $10 \%$ for the gray, air-dried seeds collected October 10 to less than $1 \%$ for green, dried seeds collected at the same time. Most seeds had 3 to $5 \%$ moisture prior to storage and only slight differences in moisture content existed between air-dried and dried seeds. Apparently the relatively lower moisture of dried seeds reduced seed viability compared to those air-dried.

Drying decreased germination of the gray variety from $54.7 \%$ to $47.1 \%$. However, drying did not affect the germination of the green variety compared to air-drying (29.2 to $29.3 \%$, respectively).

\section{Storage}

Three months of storage $\left(21^{\circ} \mathrm{C}\right)$ improved germination significantly $(p<.05)$. It improved germination of the gray variety from $49.4 \%$ immediately after harvest to $52.4 \%$ while the germination of the green variety increased from $28.1 \%$ with no storage to $30.4 \%$ with 3 month storage.

\section{Storage Temperature}

Seeds stored for 3 months were significantly $(p<.05)$ affected by storage temperature (Table 1). Germination was greater $(p<.05)$ for seeds stored a $4^{\circ} \mathrm{C}(53.6 \%)$ than those stored at $21^{\circ} \mathrm{C}(41.4 \%)$, or those stored at $-18^{\circ} \mathrm{C}(37.1 \%)$. This relationship remained constant within variety. Germination of seeds stored at -18 , and $21^{\circ} \mathrm{C}$ was not different $(p<.05)$ for the green variety; however, $4^{\circ} \mathrm{C}$
Table 1. Percent germination of Kochia prostrata var. canescens (gray) and $K$. prostrate var. virescens (green) following 3 months of storage at selected temperatures. Germination trials were conducted for 30 days. Values 1 presented are means of $\mathbf{5 0}$ samples.

\begin{tabular}{lccc}
\hline \hline & \multicolumn{3}{c}{ Storage temperature $\left({ }^{\circ} \mathrm{C}\right)$} \\
\cline { 2 - 4 } Variety & $-18^{\circ}$ & $4^{\circ}$ & $21^{\circ}$ \\
\hline Gray & $46.7^{\mathrm{a}}$ & $69.4^{\mathrm{c}}$ & $52.4^{\mathrm{b}}$ \\
Green & $27.6^{\mathrm{a}}$ & $37.9^{\mathrm{b}}$ & $30.4^{\mathrm{a}}$ \\
\hline
\end{tabular}

'Values within a variety followed by the same letter are not significantly different $(m<.05)$.

storage was different and provided the highest germination (37.9\%). Drying procedure continued to exert a significant effect on germination averaged over storage temperature. Air-dried seeds germinated better for both varieties, regardless of storage temperature.

The interaction of harvest date and storage temperature with germination for each air-dried variety provided valuable information on the management procedures required to achieve maximum germination (Fig. 3). The gray variety collected November 9, airdried, and stored 3 months at $4^{\circ} \mathrm{C}$ had the highest germination $(97 \%)$. The highest germination $(74 \%)$ for the green variety occurred under the same conditions. However, the variance associated with the mean germination for the green variety was $34.0 \%$ while that of the sample population for the gray variety was only 8.5\%. This greater variability between replications for the green
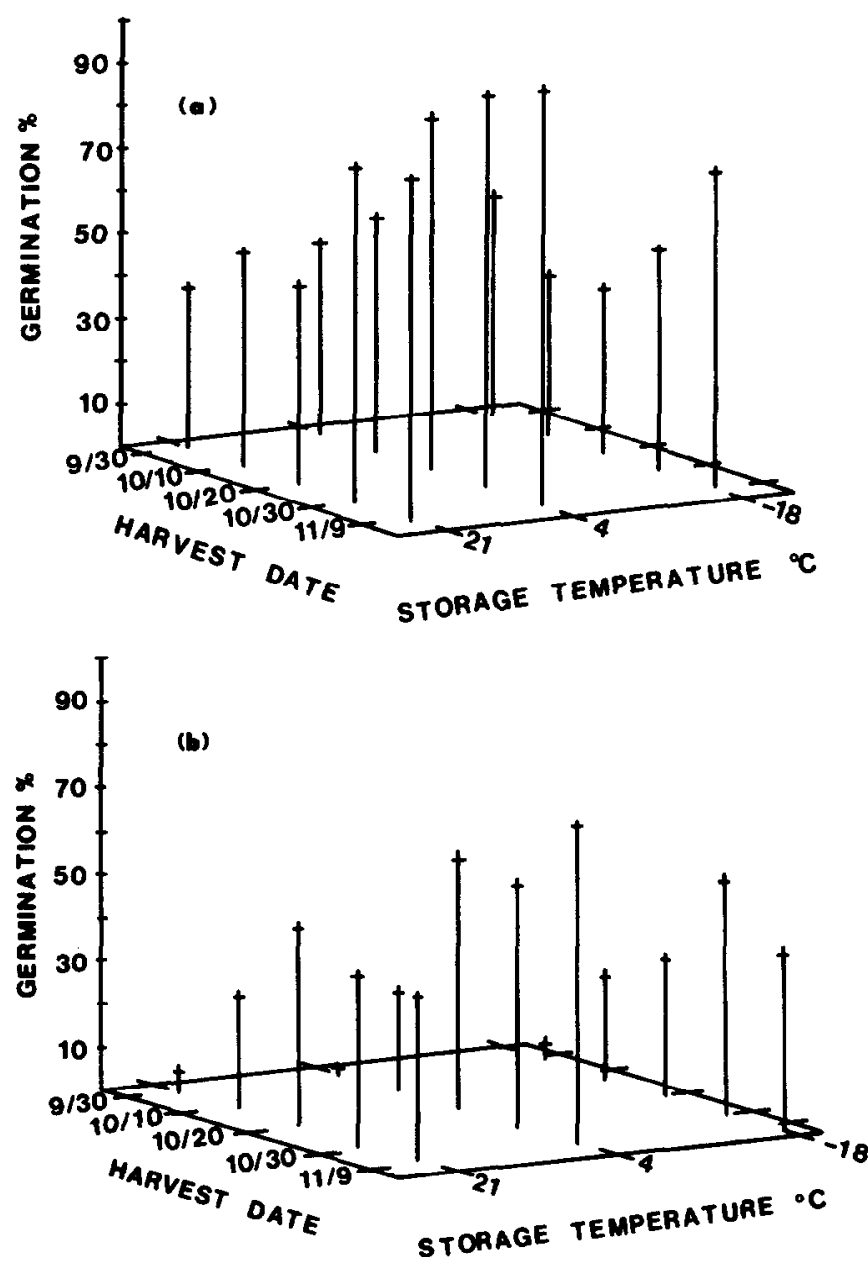

Fig. 3. The effect of harvest date and 3-month storage temperature on 30day germination for Kochia prostrata var. canescens (gray) (a) and $\mathbf{K}$. prostrata var. virescens (green) (b) seeds which were air-dried following harvest. Values were calculated using a sample size of 5. 


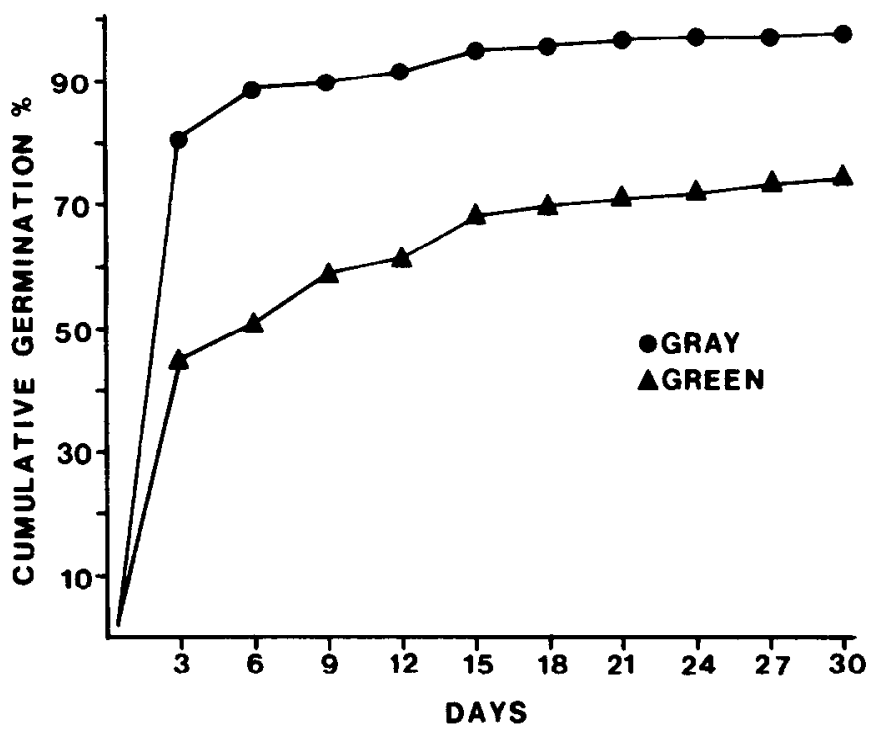

Fig. 4. The effect of time (day) on the cumulative germination percentage of Kochia prostrata var. canescens (gray) and K. prostrata var. virescens (green) harvested on November 11, 1978, air-dried and stored for three months at $4^{\circ} \mathrm{C}$. Values were calculated using a sample size of 5.

variety reflected the inconsistent germination achieved compared with the gray seeds. Under optimum conditions of harvest date, drying procedure, storage time and temperature, $81 \%$ of the gray seeds germinated within the first three days while only $45 \%$ of the green variety had germinated (Fig. 4).

\section{Conclusions}

Variation between years because of precipitation, length of growing season, and mean daily temperature may affect the germination characteristics of both varieties. For $K$. prostrata seed harvested at the end of the 1978 growing season at the Squaw Butte Station, Burns, Ore., variety, harvest date, drying procedure, stor- age and storage temperature all affected germination. K. prostrata var. canescens harvested on November 9, 1978, air-dried and stored for 3 months at $4^{\circ} \mathrm{C}$ produced the highest percentage germination $(97 \%)$. The same management procedure for seed handling and processing also produced the highest percentage but lower germination for $K$. prostrata var. virescens $(74 \%)$. Consequently, based on this germination data, the gray variety would be the more desirable variety for revegetation. Seed harvest should occur when the seed is easily hand stripped from the inflorescence. This occurred after the stems changed to a reddish color. After harvest seed should be air-dried and placed in storage for 3 months at $4^{\circ} \mathrm{C}$ prior to seeding.

\section{Literature Cited}

Balyan, G.A. 1972. Prostrate summer cypress and its culture in Kirghizia. (Transl. from Russian) 261 p. Al Ahram Cen. Sci. Transl., Nat. Tech. Information Ser. TT77-59026.

Blauer, C.A., P. Plummer, E.D. McArthur, R. Stevens, and B.C. Giunta. 1976. Characteristics and hybridization of important intermountain shrubs. II Chenopod Family. USDA Forest Ser. Res. Paper Int-177.

Britton, C.M., and F.A. Sneva. 1977. Production and chemical attributes of Kochia prostrata, p. 9-12. In: Ore. Agr. Exp. Sta. Spec. Rep. No. 480: Corvallis, Ore.

Davis, A.M. 1979. Forage quality of prostrate kochia compared with three browse species. Agron. J. 71:822-824.

Demin, Y., A. Markin, and V. Smagin. 1977. The storage of Kochia prostrata seeds. Herbage Abstr. 47:628.

Francois, L.E. 1976. Salt tolerance of prostrate summer cypress (Kochia prostrata). Agron. J. 68:455-456.

Keller, W., and A.T. Bleak. 1974. Kochia prostrata: a shrub for western ranges. Utah Sci. 35:24-25.

McArthur, E.D., B.C. Guinta, and A.P. Plummer. 1974. Shrubs for restoration of depleted ranges and disturbed areas. Utah Sci. 34:28-33.

Shetler, S.G., and L.E. Skog. 1978. A provisional checklist of species for flora North American (revised). Montana Bot. Garden. St. Louis, Mo.

Shishkin, B.K. (ed.). 1936. Flora of the USSR: (Transl. from Russian) 1970. p. 100-101. Israel Program Sci. Transl. Ltd. IPST. Cat:5402.

Steel, R.G.D., and J.H. Torrie. 1960. Principles and procedures of statistics. McGraw-Hill Book Co., Inc. New York. 